\title{
Application of HPLC method in determination of miconazole nitrate in environmental samples from el-gharbia governorate in Egypt
}

\begin{abstract}
This paper describes an enhanced High-performance liquid chromatography (HPLC) method for the analysis of miconazole in water samples. In this study, determination of miconazole has been carried out according to standard method for water and wastewater analysis. Samples of collected water were agriculture stream water, River Nile (Surface water samples) water and Hospital wastewater samples from El-gharbia governorate in Egypt. Miconazole was extracted by liquid-liquid extraction and analyzed by HPLC. The chromatographic separation was performed using a Phenomenex C8 column, flow rate of $0.8 \mathrm{~mL} / \mathrm{min}$, and UV detection at $220 \mathrm{~nm}$. The optimized HPLC system was achieved using mobile phase composition containing methanol: water $(85: 15 \mathrm{v} / \mathrm{v})$. The intra-day and interday precisions were lower than 0.58 while the accuracy ranged from $99.06 \%$ to $101.53 \%$. Finally, liquid-liquid phase extraction in combination with HPLC is a sensitive and effective method for the determination of Miconazole Nitrate in water samples. Miconazole was observed in some agricultural streams and waste water samples of El-gharbia governorate hospitals.
\end{abstract}

Keywords: determination, miconazole nitrate, water samples, HPLC chromatography.
Volume 8 Issue 4 - 2019

\author{
Mohamed W Ibrahim,' Ahmad A Mohamad,' \\ Ahmed MAhmed ${ }^{3}$ \\ 'Department of Pharmaceutical Analytical Chemistry,Al-Azhar \\ University, Egypt \\ 2Department of Pharmaceutical Analytical Chemistry \\ Department, Heliopolis University, Egypt \\ ${ }^{3}$ Pharmacist Research Laboratories, Egypt
}

Correspondence: Ahmed M Ahmed, Pharmacist Research Laboratories, Ministry of health, Giza, Egypt, Tel +201 I 19538 I 19, Email ahmedabdrabou3।@yahoo.com

Received: August 06, 2019 | Published: August 14,2019
Abbreviations: HPLC, high-performance liquid chromatography; LLE, liquid-liquid extraction; SPE, solid phase extraction; GC, gas chromatography; FID, flame ionization detector; MS, mass spectrometry

\section{Introduction}

Miconazole]1-(2,4-Dichloro-beta-((2,4-dichlorobenzyl)oxy) phenethyl)imidazole [is an anti-fungal medication related to fluconazole, ketoconazole, itraconazole, and clotrimazole. It is used either on the skin or in the vagina for fungal infections. Miconazole was approved by the FDA in 1974. Miconazole prevents fungal organisms from producing vital substances required for growth and function. This medication is effective only for infections caused by fungal organisms. It will not work for bacterial or viral infections. ${ }^{1}$ Miconazole comes as a cream, lotion, powder, spray liquid, and spray powder to be applied to the skin. It also comes as a cream and suppository to be inserted into the vagina. ${ }^{2}$ Miconazole has a molecular formula of $\mathrm{C}_{18} \mathrm{H}_{14} \mathrm{C}_{14} \mathrm{~N}_{2} \mathrm{O}$ and molecular weight of $416.127 \mathrm{~g} / \mathrm{mol} .^{3}$ Determination of miconazole in environmental water samples usually requires the application of sample preparation procedures to extract the analyte from the aqueous solution and bring it to a suitable concentration level prior to final HPLC or GC analysis. Liquid-liquid extraction (LLE) and solid phase extraction (SPE) are commonly used for the extraction of miconazole. Literature survey revealed a validation of a chromatographic method for miconazole assay from oral sustained release muco-adhesive tablets. ${ }^{4}$

Development of high performance liquid chromatography method for miconazole analysis in powder sample, ${ }^{5}$ simultaneous determination of Miconazole Nitrate and Metronidazole in different pharmaceutical dosage forms by Gas Chromatography and Flame Ionization Detector (GC-FID) ${ }^{6}$ development and validation of an extractive spectro-photometric method for miconazole nitrate assay in pharmaceutical formulations. ${ }^{7}$ Validation of a solid-phase extraction and liquid chromatography-electro spray tandem mass spectrometric method for the determination of nine basic pharmaceuticals in wastewater and surface water samples, ${ }^{8}$ determination of drugs of abuse in water by solid-phase extraction, derivatisation, gas chromatography-ion trap-tandem mass spectrometry ${ }^{9}$ and application of GC-MS in determination of malathion in environmental samples. ${ }^{10}$ The objective of this study was to develop a HPLC method for determination of miconazole in water samples. Then the developed method was validated for linearity, precision, accuracy and robustness.

\section{Materials and methods}

\section{Chemicals and Solvents}

Miconazole Nitrate $99.5 \%$ was kindly provided by Egyptian international center for import. Structural formula of miconazole is shown in Figure 1. Organic solvents methanol (HPLC gradient grade) all these chemicals were of analytical grade and all were purchased from Sigma-Aldrich (Steinheim, Germany). Deionized water (WP 4100 reagent grade water purifier-SMEG) was used for standard and sample preparations.

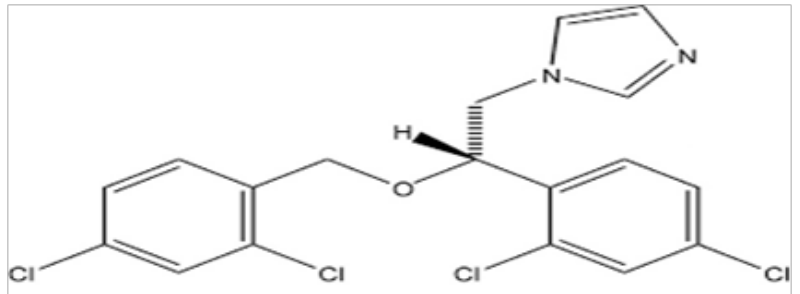

M.WT. $=416.127$

Figure I Structural formula of miconazole.

\section{Instrumentation}

HPLC Instrument: The HPLC system used was Hitachi L-2000 series (Japan), equipped with a Model L-2130 pump, an L injection loop and a UV-Vis detector L2420. The separation was carried out in a 
Phenomenex C8 column Luna $10 \mu(150 \times 4.6 \mathrm{~mm})$. The on-line solvent vacuum degasser, an auto sampler with 5 mobile phase consisted of methanol: water $(85: 15 \mathrm{v} / \mathrm{v})$. The system was operated isocratically at flow rate $0.8 \mathrm{~min} / \mathrm{mL}$ and UV wavelength $220 \mathrm{~nm}^{5}{ }^{5}$

\section{Analytical method}

Preparation of standard stock solution: Standard stock solution of Miconazole was prepared by dissolving $5 \mathrm{mg}$ standard Miconazole in $10 \mathrm{~mL}$ of methanol. Miconazole working solutions in the desired concentration range was prepared by appropriate dilution of standard stock solution with mobile phase. The prepared stock solution was kept at $4^{\circ} \mathrm{C}$ until use.

Calibration curve: A series of working standard drug solutions equivalent to $10-100 \mu \mathrm{g} \mathrm{mL}^{-1}$ for Miconazole was prepared by diluting the stock standard solution with the methanol. Standard solutions were found to be stable during the analysis time. To construct the calibration curve six replicates of each standard solution were injected immediately after preparation into the column and the peak area of the chromatograms were measured. Then, the mean peak area was plotted against the corresponding concentration of Miconazole to obtain the calibration graph. Calibration curve of miconazole was shown in Figure 2 .

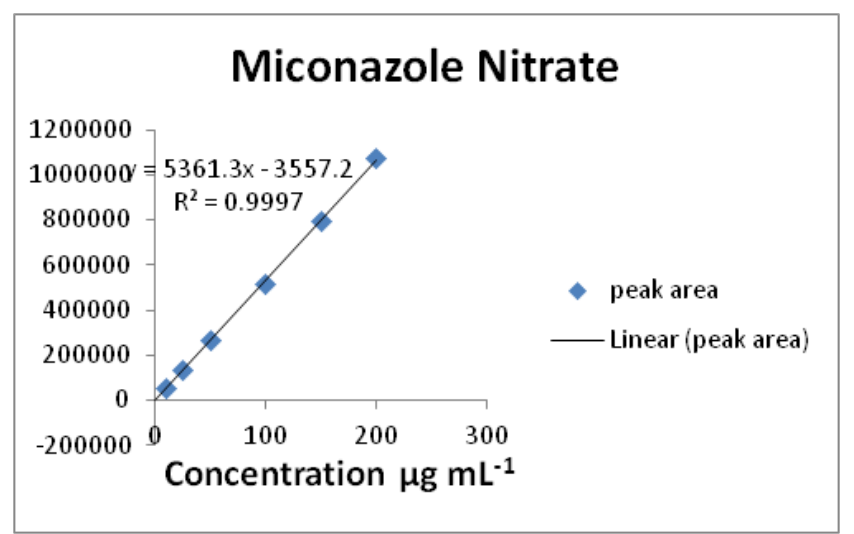

Figure 2 Calibration curve of miconazole.

Collection of water samples: A total of 60 water samples were collected in amber glass bottles in April 2018. Samples of collected water were agriculture stream water, River Nile water and Hospital wastewater samples from El-gharbia governorate: (Before the outlet of Tala stream, Tala stream, River Nile Complex Companies, Basion region, Kafr El Dawar Village, Residential block in Zifta, Zifta General Hospital, Before the outlet of Meet El nasara, Meet El nasara stream, Al-Qassed Canal in Dafra, Residential block in Al etwa elqablia, Tenth of Ramadan region, Residential block in Shakarf, Kafr El Zayat General Hospital, Al Sunta, Meet El Mokhles, biltaj, kafar hjazy, Manshawy General Hospital in Tanta and Samannoud General Hospital) (3 samples each). Coordinates of sampling locations were shown in Table 1.

Sampling: Water samples $2.5 \mathrm{~L}$ were collected in glass bottles at $50 \mathrm{~cm}$ below water level. Waters were collected by qualified personnel using standard sampling field protocol. The bottles were covered with screw caps and the samples were then stored at $4^{\circ} \mathrm{C}$ until extraction and analysis.

Extraction of miconazole from water samples: Extraction of Miconazole from water samples was performed using liquid-liquid phase extraction procedure. A measured volume of $1 \mathrm{~L}$ of the sample was transferred in a $2 \mathrm{~L}$ separation funnel and was extracted twice with $60 \mathrm{~mL}$ of $15 \%$ methylene chloride in hexane. The samples were shaken vigorously; the organic layer was taken and dried over anhydrous sodium sulfate and evaporated in a rotating evaporator. The volume of solution was attained to $10 \mathrm{~mL}$ with mobile phase. $3 \mu 1$ of each extracted solution was injected into the HPLC. ${ }^{11}$ Table 2 contains a summary of Miconazole concentrations in samples collected during the study.

Table I Coordinates of sampling locations

\begin{tabular}{|c|c|c|c|}
\hline No & Sampling locations & $\mathbf{N}$ & $\mathbf{E}$ \\
\hline I & $\begin{array}{l}\text { Before the outlet of Tala } \\
\text { stream }\end{array}$ & 30.79226 & 30.79649 \\
\hline 2 & Tala stream & 30.827569 & 30.804606 \\
\hline 3 & $\begin{array}{l}\text { River Nile Complex } \\
\text { Companies kafr el zayat }\end{array}$ & 30.8236 & 30.81137 \\
\hline 4 & Basion region & 30.93826 & 30.78215 \\
\hline 5 & Kafr El DawarVillage & 31.020441 & 30.7216948 \\
\hline 6 & Residential block in Zifta & 30.724708 & 31.252347 \\
\hline 7 & Zifta General Hospital & 30.712162 & 31.250128 \\
\hline 8 & $\begin{array}{l}\text { Before the outlet of Meet } \\
\text { El nasara }\end{array}$ & 30.93642 & 30.25237 \\
\hline 9 & Meet El nasara stream & 30.94109 & 31.245058 \\
\hline 10 & Al - Qassed Canal in Dafra & 31.028206 & 30.730023 \\
\hline II & Al etwa elqablia & 31.002042 & 30.934112 \\
\hline 12 & Tenth of Ramadan region & 30.790235 & 30.97212 \\
\hline 13 & Shakarf & 30.885279 & 30.912863 \\
\hline 14 & $\begin{array}{l}\text { Kafr El Zayat General } \\
\text { Hospital }\end{array}$ & 30.836151 & 30.818528 \\
\hline 15 & Al Sunta & 30.746967 & 31.133272 \\
\hline 16 & Meet El Mokhles & 30.7844885 & 31.1583957 \\
\hline 17 & Biltaj & $30.497|5|$ & 31.003477 \\
\hline 18 & kafar hjazy & 30.947139 & 31.162244 \\
\hline 19 & $\begin{array}{l}\text { El-Menshawy General } \\
\text { Hospital in Tanta }\end{array}$ & 30.789354 & 31.001314 \\
\hline 20 & Samannoud General Hospital & 30.965763 & $31.2434 I I$ \\
\hline
\end{tabular}


Table 2 Contains a summary of miconazole concentrations in samples collected during the study

\begin{tabular}{|c|c|c|}
\hline No. & Sampling locations & $\begin{array}{l}\text { Found concentration } \\
\text { (Mean士SD) }\end{array}$ \\
\hline I & $\begin{array}{l}\text { Before the outlet of Tala } \\
\text { stream }\end{array}$ & not detected \\
\hline 2 & Tala stream & $12.07 \pm 0.73$ \\
\hline 3 & $\begin{array}{l}\text { River Nile Complex } \\
\text { Companies kafr el zayat }\end{array}$ & not detected \\
\hline 4 & Basion region & not detected \\
\hline 5 & Kafr El Dawar Village & not detected \\
\hline 6 & Residential block in Zifta & not detected \\
\hline 7 & Zifta General Hospital & $15.03 \pm 0.25$ \\
\hline 8 & $\begin{array}{l}\text { Before the outlet of Meet El } \\
\text { nasara }\end{array}$ & not detected \\
\hline 9 & Meet El nasara stream & not detected \\
\hline 10 & Al - Qassed Canal in Dafra & not detected \\
\hline 11 & Al etwa elqablia & not detected \\
\hline 12 & Tenth of Ramadan region & not detected \\
\hline 13 & Shakarf & not detected \\
\hline 14 & $\begin{array}{l}\text { Kafr El Zayat General } \\
\text { Hospital }\end{array}$ & $13.14 \pm 0.82$ \\
\hline 15 & Al Sunta & not detected \\
\hline 16 & Meet El Mokhles & not detected \\
\hline 17 & Biltaj & not detected \\
\hline 18 & kafar hjazy & not detected \\
\hline 19 & $\begin{array}{l}\text { El-Menshawy General } \\
\text { Hospital in Tanta }\end{array}$ & $22.23 \pm 0.54$ \\
\hline 20 & Samannoud General Hospital & $20.19 \pm 0.47$ \\
\hline
\end{tabular}

\section{Results}

\section{Optimization of chromatographic condition}

Methanol-water $(85: 15 \mathrm{v} / \mathrm{v})$, flow rate $0.8 \mathrm{~mL} / \mathrm{min}$, and UV detector wavelength $220 \mathrm{~nm}$ have been chosen as the optimized HPLC condition for determination of Miconazole Nitrate in different water samples because it gave the best baseline of miconazole peak (base to base), standard solution of Miconazole was shown in Figure 3.

\section{Method validation}

The analytical method for quantification of miconazole has been validated for linearity, precision, accuracy, and robustness following appropriate recommendations of the ICH Q2 (R1) regulatory guidelines recommendations. ${ }^{12}$

\section{Linearity}

Six working standard solutions of Miconazole in the concentration of $10-100 \mu \mathrm{g} \mathrm{mL}^{-1}$ was prepared in triplicate and injected. Calibration graphs were plotted between concentration and mean peak area. Analytical parameters and linear regression data of miconazole were shown in Table 3.

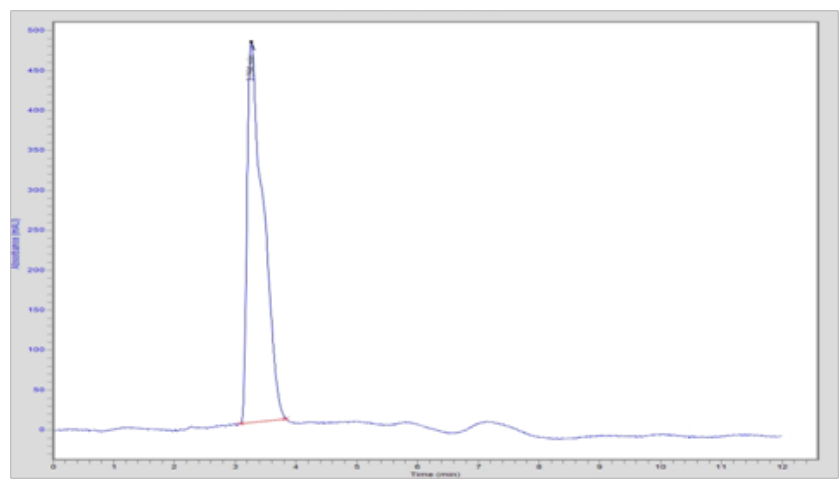

Figure 3 GC-MS chromatogram of miconazole $100 \mu g \mathrm{~mL}^{-1}$.

Table 3 Analytical parameters and linear regression data of miconazole

\begin{tabular}{ll}
\hline Parameter & \\
\hline Linearity range $(\mu \mathrm{g} \mathrm{mL}-1)$ & $10-200$ \\
LOD $\left(\mu \mathrm{g} \mathrm{mL}^{-1}\right)$ & 7.46 \\
LOQ $\left(\mu \mathrm{g} \mathrm{mL}{ }^{-1}\right)$ & $22.6 \mathrm{I}$ \\
Regression equation* & \\
Correlation coefficient & 0.999 \\
Slope (b) & 5316 \\
Intercept (a) & 3557 \\
\hline
\end{tabular}

\section{Accuracy and precision}

The accuracy and precision were determined at three different concentration levels $\left(10,50\right.$ and $\left.100 \mu \mathrm{g} \mathrm{mL}^{-1}\right)$ in terms of both intra and inter-day precision. For intra-day precision three distinct concentrations of Miconazole in the linearity range was prepared in triplicate and was analyzed on the same day. For inter-day precision the same concentrations were analyzed on three consecutive days and RSD values were calculated. Instrument precision was analyzed by injection repeatability. The accuracy and precision were calculated and expressed in terms of percent recovery and standard deviation, respectively and shown in Table 4.

\begin{tabular}{|c|c|c|c|c|c|}
\hline \multirow[t]{2}{*}{ Drug } & \multirow[t]{2}{*}{$\begin{array}{l}\text { Concen- } \\
\text { tration } \\
(\mu g / m l)\end{array}$} & \multicolumn{4}{|c|}{$\begin{array}{l}\text { The concentration found ( } \mu \text { g/ } \\
\text { L) } \pm S D ; \text { RSD }\end{array}$} \\
\hline & & $\begin{array}{l}\text { intraday } \\
\text { precision }\end{array}$ & accuracy & $\begin{array}{l}\text { interday } \\
\text { precision }\end{array}$ & $\begin{array}{l}\text { accu- } \\
\text { racy }\end{array}$ \\
\hline \multirow[t]{3}{*}{ Miconazole } & 10 & $\begin{array}{l}9.97 \pm 0.81 \\
0.82\end{array}$ & 99.73 & $\begin{array}{l}9.91 \pm 1.27 \\
1.29\end{array}$ & 99.06 \\
\hline & 50 & $\begin{array}{l}50.37 \pm 0.57 \\
; 0.58\end{array}$ & 100.74 & $\begin{array}{l}50.77 \pm 0.84 \\
; 0.85\end{array}$ & 101.53 \\
\hline & 100 & $\begin{array}{l}99.97 \pm 0.57 \\
; 0.58\end{array}$ & 99.97 & $\begin{array}{l}99.11 \pm 0.68 \\
; 0.69\end{array}$ & 99.11 \\
\hline
\end{tabular}

\section{Robustness}

Robustness is an important aspect of method validation for chromatographic methods. The influence of small deliberate changes 
in the operations (variations) of the analytical procedure is evaluated from measured or calculated responses. This is to verify that the method performance is not affected by typical changes in normal experiments. Robustness was evaluated by changing the flow rate $\left(0.8 \pm 0.1 \mathrm{ml} \mathrm{min}^{-1}\right)$. The measured response variances were the $\%$ RSDs and shown in Table 5. The effect of different UV detector wavelength was also investigated in this study. UV detection was varied in three different wavelengths 210, 220 and 230nm, UV detector wavelength $220 \mathrm{~nm}$ has been chosen as the optimized wavelength.

Table 5 Robustness data

\begin{tabular}{lll}
\hline Parameter & Validation & \%RSD of the area miconazole \\
\hline Flow rate & $0.7 \mathrm{ml} / \mathrm{min}(\mathrm{low})$ & 0.47 \\
& $0.9 \mathrm{ml} / \mathrm{min}$ (high) & 0.54
\end{tabular}

\section{Discussion}

This study aims to detect miconazole nitrate in environmental samples using the HPLC method. Our new concept is to use a simplified method to determine concentration of Miconazole nitrate in the environment and follow-up development. To achieve accurate, rapid and effective separation of miconazole in a limited time, simple mobile phase was used for evaluation. Optimal conditions for the separation of miconazole and matrix peaks established were as follows: mobile phase that consisted of methanol: water $(85: 15 \mathrm{v} / \mathrm{v})$, isocratic elution at a flow rate of $0.8 \mathrm{~mL} / \mathrm{min}$ and UV detection 220 . According to the requirements of ICH (2005), these conditions were found to be most suitable for separation and quantification of miconazole. The results of that analyzes showed that all water samples collected and analyzed were completely free of miconazole. However, it was observed in some agricultural streams and Hospital waste water samples. These results are consistent with the results of other studies conducted by some colleagues in the field of work. These results are expected as a result of the frequent and poor use of miconazole in hospitals or from some patients, whether in the treatment of skin or oral diseases and thus caused the presence in these places at these rates mentioned.

The results of this study are identical to the results of another research I have prepared with some colleagues but using GCMS device where it was found that the two methods are valid for the detection of miconazole nitrate in environmental samples (Development of a method for the determination of Miconazole in Water Samples using Gas Chromatography Mass Spectrometry) is a research that has not yet been published but has been prepared in the current period under review. Considering the conclusions of the study presented shows that the presence of ratios of miconazole in some samples, which causes a lot of health and environmental risks in the case of accumulation of these substances and misuse and this is a new understanding of this problem (misuse negatively and exacerbates the problem and does not give good solutions). Therefore, I suggest trying to limit the use of these substances that may affect public health and the environment while improving the medical care of patients and full supervision of their treatment and determine the quantities and method of optimal use in order to avoid such risks. The next step is the detection of miconazole nitrate in environmental samples in Egypt, taking into account the detection of miconazole degradation products so that we can detect early the risk of degradation products and reduce these risks. I believe that over time, Dispose of miconazole nitrate in the wrong way or misuse and accumulation of miconazole in water will lead to major problems.

\section{Miconazole residues}

In this study, a method was developed to determine Miconazole in agriculture stream water, River Nile water and Hospital wastewater samples using the chromatography technique in El-gharbia governorate. These results indicated that, Miconazole was not observed in River Nile water in all collected samples. However, it was observed in some agricultural streams and Hospital wastewater samples (Tala stream, Zifta general hospital, Kafr El Zayat General Hospital, El-Menshawy General Hospital in Tanta, Samannoud General Hospital). Table 2 Mean \pm SD of miconazole residue levels $(\mu \mathrm{g} / \mathrm{L})$ in water samples. The results of this research are exactly the same as the results I have developed using the GC-MS method (A search I've prepared and this search is under review now).

\section{Limitations of the study}

The most important limitations faced by this study are that the samples were withdrawn from a few places. We should have carried out the examination and analysis and extracted samples from more places and large areas covering a large part of the Egypt (From more hospitals) to obtain more comprehensive and credible results, but that would require a lot of money and Research is not funded by any organization but is a personal effort. Lack of time is also one of the important reasons and obstacles to research.

\section{Conclusion}

A validated, sensitive and accurate HPLC analytical method was developed for the analysis of Miconazole in water samples. The method was fully validated according to the ICH guidelines and presented good linearity, accuracy, precision and robustness. Miconazole was observed in some agricultural streams and Hospital wastewater samples of El-gharbia governorate hospitals. However, it was not observed in River Nile (surface water) water in all sampling locations. The proposed method can be successfully applied for determination of Miconazole in water samples using liquid-liquid extraction HPLC method.

\section{Acknowledgment}

The author acknowledges to staff members Pharmaceutical Analytical Chemistry Department, Faculty of Pharmacy Al-Azhar University, Cairo, Egypt for their co-operation throughout the whole work. Also acknowledgment goes to Research Laboratories, Ministry of health, Giza, Egypt for providing the necessary facilities and support in completing this work.

\section{Conflicts of Interest}

The authors declare that there are no conflicts of interest regarding the publication of this paper.

\section{Data availability}

The readers can access the data represented in this research article by contacting with the author on this email: mailto:ahmedabdrabou31@ yahoo.com as the data presented is his own personal experiment and work. 


\section{Funding statement}

The authors declare that there is no Funding Statement regarding the publication of this paper.

\section{References}

1. https://www.drugbank.ca/drugs/DB01110

2. https://medlineplus.gov/druginfo/meds/a601203.html

3. https://en.wikipedia.org/wiki/Miconazole

4. Birsan M, Cojocaru IC, Scutariu MM, et al. Validation of a chromatographic method for miconazole assay from oral sustained release muco-adhesive tablets. FARMACIA; 2014:62(3).

5. Hermawan D, Suwandri, Sulaeman U, et al. Development of high performance liquid chromatography method for miconazole analysis in powder sample. Materials Science and Engineering. 2017;172(1):011012 .

6. Ashour S, Kattan N. Simultaneous Determination of Miconazole Nitrate and Metronidazole in Different Pharmaceutical Dosage Forms by Gas Chromatography and Flame Ionization Detector (GC-FID). Int J Biomed Sci. (2010);6(1):13-18.

7. Eticha T, Kahsay G, Hailu T, et al. Development and Validation of an Extractive Spectrophotometric Method for Miconazole Nitrate Assay in Pharmaceutical Formulations Hindawi Journal of Analytical Methods in Chemistry. 2018;(2):1-5.
8. Van De Steene JC, Lambert WE. Validation of a solid-phase extraction and liquid chromatography-electrospray tandem mass spectrometric method for the determination of nine basic pharmaceuticals in wastewater and surface water samples. Journal of Chromatography A. 2008;1182(2):153-160.

9. González-Mariño I, Quintana JB, Rodríguez I, et al. Determination of drugs of abuse in water by solid-phase extraction, derivatisation and gas chromatography-ion trap-tandem mass spectrometry. J Chromatogr A. 2010;1217(11):1748-60.

10. Ibrahim MW, Mohamad AA, Ahmed AM. Application of GC-MS in determination of malathion in environmental samples. WJPPS. 2018;(5):135-144.

11. Ibrahim MW, Mohamad AA, Ahmed AM. Application of HPLC method with diode array for tetramethrin determination in different environmental samples from upper Egypt. $J$ Anal Pharm Res. 2019;8(4):138-142.

12. International conference on Harmonization (ICH) Q2 (R1). Validation of Analytical Procedures: Text and Methodology. 2005. 